\title{
GAMBARAN TINGKAT STRES KERJA PERAWAT RUMAH SAKIT PADA ERA NEW NORMAL
}

\author{
Tia Oktari ${ }^{1)}$, Fathra Annis Nauli ${ }^{2)}$, Hellena Deli ${ }^{3)}$ \\ ${ }^{1,2,3}$ Fakultas Keperawatan Universitas Riau Jalan Pattimura No. 09 Gedung G Pekanbaru Riau \\ Email : tiaoktari23@gmail.com
}

Diterima: April 2021, Diterbitkan: Juni 2021

\begin{abstract}
ABSTRAK
Pendahuluan: Stres kerja merupakan salah satu permasalahan yang terjadi pada era new normal terhadap perawat dalam penyesuaian bekerja akibat Covid-19. Penelitian ini bertujuan untuk mengetahui gambaran tingkat stres kerja perawat rumah sakit pada era new normal. Metode: Penelitian ini merupakan penelitian deskriptif. Sampel penelitian adalah 113 responden dengan menggunakan teknik total sampling. Pengumpulan data menggunakan kuisioner penelitian Tayyib dan Alsolami (2020) yang sudah dimodifikasi kembali oleh peneliti dan dilakukan uji validitas dengan rentang nilai $0,450-0,795 \geq \mathrm{r}$ tabel 0,444 dan uji reabilitas didapatkan $\mathrm{r}$ hasil crobach's alpha 0,923 dengan $r$ tabel 0,444. Hasil: Gambaran tingkat stres kerja perawat rumah sakit pada era new normal yang mengalami stres kerja tingkat ringan 30 orang $(26,5 \%)$, mengalami stres kerja tingkat sedang 56 orang $(49,6 \%)$ dan mengalami stres kerja tingkat berat 27 orang $(23,9 \%)$. Kesimpulan: Mayoritas responden berada pada tingkatan stres sedang. Diharapkan bagi pihak manajemen rumah sakit dapat melakukan pelatihan manajemen stres kerja serta konseling mengenai tekanan-tekanan yang dihadapi petugas kesehatan dalam melakukan perawatan terhadap pasien pada era new normal untuk meminimalisir masalah psikologis petugas kesehatan dalam bekerja.
\end{abstract}

Kata Kunci : New normal, perawat, stres kerja

\section{ABSTRACT}

Background: Work stress is one of the problem that occured in the new normal era for nurses in working adjustments due to Covid-19. This study aims to describe the level of work stress of hospital nurses in the new normal era. Methods: This research is descriptive study. The research sample was 113 respondents using total sampling technique. Data collection used research questionaire Tayyib and Alsolami (2020) which has been modified again by researcher and carried out a validity test with a value range of 0,450-0,795 $\geq r$ table 0,444 and the reability test get crobac's alpha 0,923 results with $r$ table 0,444. Results: An overview of the work stress level of hospital nurses in the new normal era who experienced mild work stress was 30 peoples (26,5\%), experienced moderate work stress 56 peoples (49,6\%) and experienced severe work stress 27 peoples (23,9\%). Conclusion: The majority of respondents are at a moderate level of work stress. It is hoped that the hospital management can carry out work stress management training and counseling regarding the pressures by health worker when treating patients in the new normal era to minimize the psychological problems of health worker at work.

Keywords : New normal, nurse, work stress 


\section{PENDAHULUAN}

Awal tahun 2020 ditemukan corona virus jenis baru yaitu SARS-CoV-2 yang diberi sebutan Covid-19, virus ini menyebar hampir di seluruh dunia. Proses penularan virus ini yaitu dari manusia ke manusia melalui percikan dari hidung atau mulut yang keluar saat seseorang yang terinfeksi Covid-19 batuk, bersin atau berbicara. Gejala yang paling umum adalah demam (suhu $>38^{\circ} \mathrm{C}$ ), batuk kering dan rasa lelah. Asal mula virus ini berasal dari Wuhan, Tiongkok yang ditemukan pada Desember 2019 (World Health Organization (WHO, 2020).

Dilihat dari data, jumlah penderita Covid-19 semakin bertambah setiap harinya. Menurut data Worldmeters (2020), virus ini telah mewabah di 215 negara dengan total kasus terkonfirmasi positif 22.342.456 kasus dengan total kematian 785,197 jiwa dan dinyatakan sembuh 15.080.456 jiwa. Negara Indonesia berada pada peringkat ke 23 dari 215 negara tersebut dengan total kasus terkonfirmasi positif 144.945 kasus dengan total kematian 6.346 jiwa dan 98.657 jiwa berhasil dinyatakan sembuh (Worldmeters, 2020)

Menurut data Dinas Kesehatan Riau pada 23 Desember 2020, dilaporkan total kasus terkonfirmasi positif di Riau sejumlah 23.980 kasus konfirmasi dengan total kematian 548 jiwa, 21.630 jiwa dinyatakan sembuh, 1.220 isolasi mandiri dan 582 sedang dirawat di RS. Kota Pekanbaru menempati posisi pertama kasus terbanyak positif Covid-19 di Riau dengan 11.280 kasus disertai total kasus kematian sejumlah 258 jiwa dan dinyatakan sembuh 10.270 jiwa (Dinkes Riau, 2020). Berdasarkan data yang semakin bertambah setiap harinya ini, masyarakat perlu beradaptasi dengan berbagai prosedur yang diterapkan pemerintah untuk meminimalisir dampak pandemi ini.

Pemerintah Indonesia melaksanakan kebijakan tanggap darurat penanganan Covid-19 sejak awal Maret 2020 yaitu dengan memodifikasi kebijakan lockdown menjadi Pembatasan Sosial Berskala Besar (PSBB) yang bersifat lokal. Selanjutnya tiga bulan setelah itu, Indonesia menerapkan kehidupan normal yang baru dan melongggarkan PSBB sebagai upaya menjaga produktivitas masyarakat dengan tatanan baru yang disebut new normal. New normal adalah kehidupan normal baru untuk hidup berdampingan dengan Covid19 serta menjaga perubahan perilaku ditambah dengan penerapan protokol kesehatan guna mencegah terjadinya penularan Covid-19 (Muhyiddin, 2020).

Pemerintah Indonesia menerapkan new normal sebagai peraturan untuk mencegah penularan Covid-19 namun tetap menjaga produktivitas masyarakat dengan mematuhi protokol kesehatan. Kenyataanya, angka terkonfirmasi positif Covid-19 semakin meningkat bahkan menyebabkan banyak petugas kesehatan yang meninggal akibat terinfeksi virus ini. Negara Indonesia berada pada persentase kematian yang cukup tinggi untuk tenaga medis yaitu 2,3 \% dengan total 181 kematian tenaga medis berdasarkan data 03 September 2020 (Worldmeters, 2020)

Petugas kesehatan yang paling banyak jumlahnya ialah perawat, perawat dituntut untuk memberikan pelayanan kepada banyak pasien setiap harinya. Namun, kurangnya kepedulian masyarakat seperti sulit diedukasi untuk tetap menggunakan masker, tidak jujur dalam berobat, physical distancing yang berjalan kurang baik menyebabkan perawat merasa khawatir terinfeksi virus ini.

Stres kerja merupakan bentuk respon psikologis dari tubuh terhadap tekanantekanan yang muncul dari interaksi antara individu dengan pekerjaanya, dan dapat merubah fungsi fisik serta psikis yang normal, sehingga dinilai membahayakan, dan tidak menyenangkan (Widyasari, 2010)

Menangani masalah stres kerja ini, maka perlu dipahami terlebih dahulu gambaran tingkat stres kerja perawat pada era new normal. 


\section{METODE PENELITIAN}

Penelitian ini dilakukan di salah satu rumah sakit swasta di kota Pekanbaru yang dimulai bulan Januari 2021 hingga Februari 2021 dengan desain penelitian deskriptif kuantitatif.

Populasi dalam penelitian ini ialah seluruh perawat yang bekerja di rumah sakit tersebut berjumlah 135 orang. Penelitian ini menggunakan teknik total sampling. Sampel dalam penelitian ini yaitu seluruh perawat di salah satu rumah sakit swasta di kota Pekanbaru dengan total 113 orang perawat.

Alat pengumpulan data dalam penelitian ini menggunakan kuisioner Tayyib dan Alsolami (2020) dalam penelitiannya yang berjudul mengukur tingkat stres dan ketakutan perawat yang terdaftar di KSA (Kerajaan Saudi Arabia) selama wabah Covid-19 yang telah dimodifikasi kembali oleh peneliti dan dilakukan uji validitas dan reabilitas. Terdapat 13 pertanyaan yang telah berhasil dilakukan diuji validitas $(0,450-0,795)$ dan uji reabilitas $(\alpha=0,923)$.

Analisis univariat dalam penelitian ini untuk melihat karakteristik responden meliputi ruangan kerja, usia, jenis kelamin, status perkawinan, tingkat pendidikan, masa kerja dan riwayat mengikuti pelatihan Covid-19 yang disajikan dalam tabel sistribusi frekuensi.

\section{HASIL DAN PEMBAHASAN}

Berdasarkan hasil penelitian yang telah dilakukan, maka diperoleh hasil sebagai berikut:
Tabel 1 : Distribusi frekuensi karakteristik responden meliputi ruangan kerja, usia, jenis kelamin, status perkawinan, tingkat pendidikan, masa kerja dan riwayat mengikuti pelatihan Covid-19

\begin{tabular}{|c|c|c|}
\hline Karaktreristik Responden & $\mathbf{F}$ & $(\%)$ \\
\hline \multicolumn{3}{|l|}{ 1.Ruangan Kerja } \\
\hline Poliklinik & 20 & 17,7 \\
\hline Lantai V (Rawat Inap Medikal) & 17 & 15,0 \\
\hline UGD & 16 & 14,2 \\
\hline ICU/ICCU/HCU & 15 & 13,3 \\
\hline Kamar Operasi & 15 & 13,3 \\
\hline $\begin{array}{l}\text { Lantai VI (Rawat Inap Covid- } \\
\text { 19) }\end{array}$ & 15 & 13,3 \\
\hline Perina/NICU & 7 & 6,2 \\
\hline Hemodialisa & 5 & 4,4 \\
\hline Endoskopi & 3 & 2,7 \\
\hline Total & 113 & 100,0 \\
\hline \multicolumn{3}{|l|}{ 2. Usia } \\
\hline Remaja Akhir (17-25 tahun) & 51 & 45,1 \\
\hline Dewasa Awal (26 -35 tahun) & 56 & 49,6 \\
\hline Dewasa Akhir (36-45 tahun) & 6 & 5,3 \\
\hline Total & 113 & 100,0 \\
\hline \multicolumn{3}{|l|}{ 3. Jenis Kelamin } \\
\hline Perempuan & 81 & 71,7 \\
\hline Laki-laki & 32 & 28,3 \\
\hline Total & 113 & 100,0 \\
\hline \multicolumn{3}{|l|}{ 4. Status Perkawinan } \\
\hline Belum Menikah & 74 & 65,5 \\
\hline Menikah & 39 & 34,5 \\
\hline Total & 113 & 100,0 \\
\hline \multicolumn{3}{|l|}{ 5. Tingkat Pendidikan } \\
\hline S1 Keperawatan/Ners & 83 & 73,5 \\
\hline D3 Keperawatan & 30 & 26,5 \\
\hline Total & 113 & 100,0 \\
\hline \multicolumn{3}{|l|}{ 6. Masa Kerja } \\
\hline$<1$ tahun & 34 & 20,1 \\
\hline 1-2 tahun & 35 & 31,0 \\
\hline$>2$ tahun & 44 & 38,9 \\
\hline Total & 113 & 100,0 \\
\hline \multicolumn{3}{|l|}{$\begin{array}{l}\text { 7. Riwayat Mengikuti Pelatihan } \\
\text { Covid-19 }\end{array}$} \\
\hline Ya & 62 & 54,9 \\
\hline Tidak & 51 & 45,1 \\
\hline Total & 113 & 100,0 \\
\hline
\end{tabular}

Berdasarkan Tabel 1 data distribusi frekuensi dari 113 responden yang diteliti, sebagian besar perawat berada di ruangan poliklinik, yaitu berjumlah 20 responden $(17,7 \%)$. Karakteristik berdasakan usia sebagian besar berada pada rentang usia dewasa awal (26 tahun - 35 tahun) yaitu berjumlah 56 responden $(49,6 \%)$. 
Karakteristik berdasarkan jenis kelamin sebagian besar perempuan yaitu 81 responden $(71,7 \%)$. Karakteristik berdasarkan data status perkawinan sebagian besar belum menikah yaitu 74 responden (65,5\%). Karakteristik berdasarkan tingkat pendidikan sebagian besar S1 Keperawatan/Ners yaitu 83 responden (73,5\%). Karakteristik berdasarkan masa kerja sebagian besar bekerja > 2 tahun yaitu 44 responden $(38,9 \%)$. Karakteristik berdasarkan riwayat mengikuti pelatihan Covid-19 sebagian besar sudah mengikuti pelatihan yaitu 62 responden $(54,9 \%)$.

Tabel 2: Tingkatan stres kerja perawat

\begin{tabular}{lcc}
\hline \multicolumn{1}{c}{ Tingkat Stres Kerja } & F & $(\mathbf{\% )}$ \\
\hline Stres Ringan & 30 & 26,5 \\
Stres Sedang & 56 & 49,6 \\
Stres Berat & 27 & 23,9 \\
\hline Total & 113 & 100,0 \\
\hline
\end{tabular}

Berdasarkan Tabel 2 data tingkatan stres kerja perawat mayoritas berada pada tingkatan stres kerja tingkat sedang yaitu 56 responden $(49,6 \%)$. Sedangkan perawat yang berada pada tingkatan stres kerja tingkat ringan berjumlah 30 responden $(26,5 \%)$ dan responden yang berada pada tingkatan stres kerja berat berjumlah 27 responden $(23,9 \%)$.

Data tingkatan stres kerja perawat berdasarkan karakteristik responden ruangan kerja, sebagian besar berada pada tingkatan stres sedang. Sedangkan ruangan UGD sebagian besar berada pada tingkatan stres kerja tingkat ringan yaitu 8 responden (50\%), ruangan ICU/ICCU/HCU berada pada tingkatan stres berat dengan 7 responden $(46,7 \%)$ serta ruangan endoskopi sebagian besar berada pada tingkatan stres kerja tingkat berat dengan 2 responden (66,7\%). Berdasarkan data karakteristik usia responden sebagian besar berada pada tingkatan stres kerja tingkat sedang kecuali rentang usia dewasa akhir (36-45 tahun) berada pada tingkatan stres ringan yaitu 4 responden (66,6\%). Berdasarkan data karakteristik responden jenis kelamin, sebagian besar perempuan berada pada tingkatan stres kerja tingkat sedang dengan 44 responden $(54,3 \%)$ dan laki-laki berada pada tingkatan stres ringan yaitu 13 responden (40,6\%). Berdasarkan data karakteristik status perkawinan, sebagian besar berada pada tingkatan stres sedang baik yang belum menikah $(53 \%)$ maupun yang sudah menikah $(51,3 \%)$. Beradasarkan tingkat pendidikan, mayoritas berada pada tingkatan stres sedang untuk lulusan S1 Keperawatan/Ners (53\%) dan D3 Keperawatan (40\%) juga berada pada tingkatan stres sedang. Berdasarkan data karakteristik masa kerja responden sebagian besar responden berada dalam tingkatan stres kerja tingkat sedang. Berdasarkan data, responden dengan masa kerja $1-2$ tahun berjumlah 22 responden berada pada tingkatan stes kerja tingkat sedang $(62,9 \%)$ dan masa kerja $>2$ tahun berada pada tingkatan stres kerja tingkat sedang pula, dengan jumlah 21 responden $(47,7 \%)$. Sedangkan responden dengan masa kerja $<1$ tahun berada pada tingkatan stres kerja tingkat ringan, dengan jumlah 15 responden $(44,1 \%)$. Berdasarkan data riwayat mengikuti pelatihan Covid-19 sebagian besar perawat berada pada tingkatan stres sedang, baik yang sudah mengikuti pelatihan $(38,7 \%)$ begitu juga yang belum pernah mengikuti pelatihan $(62,7 \%)$. (Tabel 3). 
Tabel 3 : Tingkatan stres kerja berdasarkan data karakteristik responden

\begin{tabular}{|c|c|c|c|c|c|c|c|c|}
\hline \multicolumn{9}{|c|}{ Tingkatan Stres Kerja Responden } \\
\hline \multirow[t]{2}{*}{ Ruangan Kerja } & \multicolumn{2}{|c|}{$\begin{array}{c}\text { Stres } \\
\text { Ringan }\end{array}$} & \multicolumn{2}{|c|}{$\begin{array}{c}\text { Stres } \\
\text { Sedang }\end{array}$} & \multicolumn{2}{|c|}{$\begin{array}{l}\text { Stres } \\
\text { Berat }\end{array}$} & \multicolumn{2}{|c|}{ Total } \\
\hline & $\mathbf{F}$ & $(\%)$ & $\mathbf{F}$ & $(\%)$ & $\mathbf{F}$ & (\%) & $\mathbf{F}$ & (\%) \\
\hline \multicolumn{9}{|l|}{ 1. Ruangan Kerja } \\
\hline Poliklinik & 5 & 25,0 & 11 & 55,0 & 4 & 20,0 & 20 & 100,0 \\
\hline \multirow{2}{*}{\multicolumn{9}{|c|}{ Medikal) }} \\
\hline & & & & & & & & \\
\hline UGD & 8 & 50,0 & 4 & 25,0 & 4 & 25,0 & 16 & 100,0 \\
\hline ICU/ICCU/HCU & 2 & 13,3 & 6 & 40,0 & 7 & 46,7 & 15 & 100,0 \\
\hline Kamar Operasi & 4 & 26,7 & 9 & 60,0 & 2 & 13,3 & 15 & 100,0 \\
\hline Lantai VI (Rawat Inap & 4 & 26,7 & 10 & 66,7 & 1 & 6,7 & 15 & 100,0 \\
\hline \multicolumn{9}{|l|}{ Covid-19) } \\
\hline Perina/NICU & 1 & 14,3 & 4 & 57,1 & 2 & 28,6 & 7 & 100,0 \\
\hline Hemodialisa & 1 & 20,0 & 3 & 60,0 & 1 & 20,0 & 5 & 100,0 \\
\hline Endoskopi & 0 & 0,0 & 1 & 33,3 & 2 & 66,7 & 3 & 100,0 \\
\hline Total & 30 & 26,5 & 56 & 49,6 & 27 & 23,9 & 113 & 100,0 \\
\hline \multicolumn{9}{|l|}{ 2. Tingkatan Usia } \\
\hline Remaja Akhir (17-25 tahun) & 17 & 33,3 & 20 & 39,2 & 14 & 27,5 & 51 & 100,0 \\
\hline Dewasa Awal ( $26-35$ tahun) & 9 & 16,1 & 30 & 53,6 & 17 & 30,3 & 56 & 100,0 \\
\hline Dewasa Akhir (36-45 tahun) & 4 & 66,6 & 1 & 16,7 & 1 & 16,7 & 6 & 100,0 \\
\hline Total & 30 & 26,6 & 51 & 45,1 & 32 & 28,3 & 113 & 100,0 \\
\hline \multicolumn{9}{|l|}{ 3. Jenis Kelamin } \\
\hline Perempuan & 17 & 21,0 & 44 & 54,3 & 20 & 24,7 & 81 & 100,0 \\
\hline Laki-laki & 13 & 40,6 & 12 & 37,5 & 7 & 21,9 & 32 & 100,0 \\
\hline Total & 23 & 20,4 & 72 & 63,7 & 18 & 15,9 & 113 & 100,0 \\
\hline \multicolumn{9}{|l|}{ 4. Status Perkawinan } \\
\hline Belum Menikah & 21 & 28,4 & 36 & 48,6 & 17 & 23,0 & 74 & 100,0 \\
\hline Menikah & 9 & 23,1 & 20 & 51,3 & 10 & 25,6 & 39 & 100,0 \\
\hline Total & 30 & 26,5 & 56 & 49,6 & 27 & 23,9 & 113 & 100,0 \\
\hline \multicolumn{9}{|l|}{ 5. Tingkat Pendidikan } \\
\hline S1 Keperawatan/Ners & 22 & 26,5 & 44 & 53,0 & 17 & 20,5 & 83 & 100,0 \\
\hline D3 Keperawatan & 8 & 26,7 & 12 & 40,0 & 10 & 33,3 & 30 & 100,0 \\
\hline Total & 30 & 26,5 & 56 & 49,6 & 27 & 23,9 & 113 & 100,0 \\
\hline \multicolumn{9}{|l|}{ 6. Masa Kerja } \\
\hline$<1$ tahun & 15 & 44,1 & 13 & 38,2 & 6 & 17,6 & 34 & 100,0 \\
\hline 1-2 tahun & 6 & 17,1 & 22 & 62,9 & 7 & 20,0 & 35 & 100,0 \\
\hline$>2$ tahun & 9 & 20,5 & 21 & 47,7 & 14 & 31,8 & 44 & 100,0 \\
\hline Total & 30 & 26,5 & 56 & 49,6 & 27 & 23,9 & 113 & 100,0 \\
\hline \multicolumn{9}{|c|}{ 7. Riwayat Mengikuti Pelatihan Covid-19 } \\
\hline Ya & 19 & 30,6 & 24 & 38,7 & 19 & 30,6 & 62 & 100,0 \\
\hline Tidak & 11 & 21,6 & 32 & 62,7 & 8 & 15,7 & 51 & 100,0 \\
\hline Total & 30 & 26,5 & 56 & 49,6 & 27 & 23,9 & 113 & 100,0 \\
\hline \multicolumn{4}{|c|}{$\begin{array}{l}\text { PEMBAHASAN } \\
\text { Penelitian yang dilakukan terhadap } \\
113 \text { responden ini, mayoritas perawat } \\
\text { ruangan berada pada stres kerja tingkat } \\
\text { sedang. Berdasarkan data tingkatan stres } \\
\text { per ruangannya, ruangan UGD berada } \\
\text { pada stes kerja tingkat ringan secara } \\
\text { mayoritas dengan persentase 50,0\%, } \\
\text { ruangan ICU/ICCU/HCU mayoritas }\end{array}$} & \multicolumn{5}{|c|}{$\begin{array}{l}\text { berada pada stres kerja tingkat berat } \\
\text { dengan persentase } 46,7 \% \text {, ruangan } \\
\text { endoskopi mayoritas berada pada stres } \\
\text { kerja tingkat berat dengan persentase } \\
66,7 \% \text { dan sisanya berada pada stres } \\
\text { tingkat sedang. } \\
\text { Ruangan UGD berada pada } \\
\text { tingkatan stres kerja tingkat ringan, hal ini } \\
\text { tentu sangat baik bagi ksesehatan mental } \\
\text { perawat UGD. Selama masa pandemi }\end{array}$} \\
\hline
\end{tabular}


Covid-19 perawat UGD tentu saja mengalami kesulitan dalam menghadapi pasien. Namun, jalannya triase di UGD dengan baik serta tersedianya Alat Perlindungan Diri (APD) menyebabkan kekhawatiran mereka dalam menghadapi pasien pada era new normal ini. Lebih dari $50 \%$ perawat UGD berjenis kelamin lakilaki, hal ini tentu saja sesuai dengan data tingkatan stres kerja laki-laki yang mayoritas berada pada tingkatan stres sedang.

Mayoritas perawat endoskopi mengalami stres kerja tingkat berat. Hal ini disebabkan perawat endoskopi bekerja dengan melakukan tindakan keperawatan yang bersifat aerosol. Tindakan bersifat aerosol ialah tindakan yang dilakukan dengan membuka jalan nafas sehingga menyebabkan terjadi perputaran udara di suatu rungan. Terlebih lagi, pasien yang akan dilakukan tindakan endoskopi hanya diskrining oleh rapid test saja. Pemeriksaan ini memiliki akurasi deteksi Covid-19 yang paling rendah. Tidak hanya itu, banyaknya jumlah pasien terkonfirmasi positif Covid-19 yang tanpa gejala menyebabkan kekhawatiran tersendiri bagi perawat.

Kondisi ini, senada dengan yang terjadi di ruangan ICU/ICCU/HCU mayoritas perawatnya berada pada tingkatan stres berat. Hal ini terjadi karena ketika dilakukan penelitian ini, terdapat dua orang perawat ICU/ICCU/HCU yang baru saja dinyatakan positif Covid-19. Melakukan tindakan keperawatan dalam situasi seperti ini tentu menjadi beban tersendiri bagi petugas. Vahnia et al., (2020) menyatakan resiko penularan penyakit Covid-19 ini dapat meningkatkan rasa takut terkontaminasi dari pasien diikuti dengan gangguan obsesifkompulsif dan hipokondria (Vahia et al., 2020).

Kekhawatiran dalam menghadapi pasien pada era new normal tentu semakin menegangkan dengan kondisi seperti ini. Tidak hanya itu, perawat ruangan ini setiap harinya dihadapi oleh pasien dengan kondisi kritis. Tentu saja, mereka dituntut untuk memberikan pelayanan yang baik terhadap pasien dengan kondisi kronik dan dituntut untuk cepat dan tepat dalam memberikan tindakan keperawatan guna menyelamatkan pasien. Hal ini merupakan salah satu stresor bagi petugas (Haryanti et al., 2013)

Berdasarkan usia, mayoritas responden dalam penelitian ini berada pada rentang usia produktif dimana ia memiliki kemampuan dan semangat tinggi dalam bekerja. Hal ini seusai dengan penelitian Widiastuti (2018) bahwa pada usia produktif seseorang mempunyai kekuatan untuk menyelesaikan tekanan kerjanya dengan baik. Perawat yang berada pada kelompok usia ini berada pada stres tingkat sedang dikarenakan ia mampu mengatasi stres yang dialaminya (Widiastuti, 2018).

Perawat yang berada pada rentang usia dewasa akhir dalam penelitian ini mayoritas berada pada tingkatan stres ringan, hal ini bisa jadi dikarenakan pengalaman bekerja dan kemampuan beradaptasi dengan lingkungan bagi perawat yang senior lebih mudah. Berdasarkan penelitian Jusnimar (2012) kelompok usia yang lebih tinggi jarang mengalami stres kerja dikarenakan semakin bertambahnya usia seseorang semakin mampu ia mengendalikan emosinya, berpikir rasional terbuka dengan pendapat orang lain dalam bekerja sehingga ia mampu mengontrol stres yang dialami saat bekerja (Jusnimar, 2012)

Perawat yang berada pada tingkatan stres sedang mampu memanajemen emosionalnya sehingga mencapai keseimbangan anatara bekerja dengan kehidupan mereka. Jika keseimbangan ini terus terjadi, maka tidak akan berbahaya bagi kesehatan psikologis perawat perempuan. Namun, berdasarkan data, perawat yang mengalami stres berat dalam penelitian ini berjumlah 20 orang perawat. Artinya, lebih dari seperlima perawat perempuan berada pada tingkat stres berat, angka ini termasuk beresiko bagi perawat 
perempuan. Hal ini bisa saja berkaitan dengan peran perempuan yang cukup banyak yaitu sebagai karyawan, ibu dan seorang istri. Greenberg (2013) menuturkan bahwa perempuan sulit mengatasi stres yang dialami dikarenakan perempuan mengatasi stressor secara emosional, sehingga perempuan lebih banyak meminta dukungan sosial untuk mengatasi stresnya (Greenberg, 2013)

Sedangkan data tingkatan stres kerja perawat laki-laki mayoritas bearada pada tingkatan stres ringan dengan 40,6\%. Angka ini menggambarkan bahwa manajemen tingkatan stres dalam bekerja bagi perawat laki-laki dalam penelitian ini cukup baik. Menurut Sutjiato, et al (2015) laki-laki tidak mudah mengalami stres karena laki-laki dituntut untuk lebih kuat sehingga laki-laki lebih menggunakan akalnya daripada perasaannya sehingga siap menghadapi masalah, hal inilah yang menyebabkan pria dapat melawan stres (Sujiato et al., 2015).

Berdasarkan data status perkawinan, sebagian besar perawat mengalami stres kerja tingkat sedang, baik yang belum menikah maupun sudah menikah. Status perkawinan erat kaitannya dengan tanggung jawab yang tinggi dikarenakan peran ganda seseorang yaitu sebagai pendamping hidup dan karyawan. Tanggung jawab yang tinggi ini menyebabkan petugas kesehatan memiliki resiko tinggi mengalami masalah stres dari ringan hingga berat. Menurut Kang et al (2020) petugas kesehatan memiliki ketakutan terinfeksi Covid-19, hal ini menyebabkan munculnya rasa khawatir akan menularkan keluarga yang mereka cintai. Banyak dari tenaga kesehatan yang harus mengisolasi dirinya dari keluarga dan orang terdekat meskipun ia sedang tidak terinfeksi Covid-19 (Kang et al., 2020). Hal ini menjadi beban tersendiri bagi mereka yang sudah menikah, sehingga menjadi beban psikologis tersendiri.

Berdasaran data tingkatan stres kerja tingkat pendidikan, mayoritas berada pada tingkatan stres sedang untuk lulusan S1 Keperawatan + Ners dengan $53 \%$ dan D3 Keperawatan dengan $40 \%$. Hal ini sesuai dengan teori perspektif yang menyatakan bahwa semakin tinggi tingkat pendidikan semakin meningkat pula kemampuan kopingnya dalam memecahkan masalah yang dihadapinya. Perawat yang memiliki tingkat pengetahuan yang tinggi memiliki banyak pengetahuan dan keterampilan dalam memberikan perawatan. Hal ini tentu meningkatkan rasa kepercayaan dirinya dan berpengaruh terhadap koping dirinya (Kurniasih et al., 2014).

Penelitian berdasarkan masa kerja karyawan ditemukan bahwa karyawan yang bekerja $<1$ tahun mayoritas berada pada tingkatan stres ringan dengan $44,1 \%$, masa kerja $1-2$ tahun mayoritas berada pada tingkatan stres sedang dengan 62,9\% dan masa kerja $>2$ tahun mayoritas berada pada tingkatan stres sedang dengan $47,7 \%$. Secara total, mayoritas responden berada pada tingkatan stres sedang. Penelitian ini sejalan dengan Kurniasih (2014) yaitu mayoritas responden berada pada tingkatan stres sedang. Pengalaman sangat penting dalam kemampuan dan koping individu dalam bekerja. Namun, perawat yang memiliki masa kerja lebih lama biasanya akan menurun kemampuan fisiknya akibat kelelahan (Kurniasih et al., 2014). Sedangkan menurut Marchelia (2014) perawat yang sudah memiliki pengalaman akan terbiasa dengan kondisi pekerjaan yang dilakukan setiap hari sehingga lebih kecil kemungkinan terjadinya stres dibandingkan perawat yang belum lama bekerja (Marchelia, 2014).

Begitu pula dengan perawat yang memiliki riwayat ikut pelatihan penggunakan Alat Penlindung Diri (APD) dan perawatan pasien Covid-19, didapatkan data 62 orang pernah mengikuti pelatihan dan yang belum pernah mengikuti pelatihan ini berjumlah 51 orang. Berdasarkan data tingkatan stres kerja mayoritas berada pada tingkatan stres tingkat sedang, untuk yang 
pernah mengikuti pelatihan ini $38,7 \%$ berada pada tingkatan stres sedang dan yang belum pernah mengikuti pelatihan $62,7 \%$. Disimpulkan bahwa perawat yang sudah pernah mengikuti pelatihan dan yang belum mengikuti pelatihan ini mayoritas berada pada stres kerja tingkat sedang. Pelatihan keperawatan berguna untuk mengembangkan dan meningkatkan kemampuan perawat dalam bekerja. Diadakannya pelatihan penggunaan Alat Perlindungan Diri (APD) dan perawatan pasien Covid-19 bertujuan agar perawat lebih siap menghadapi pasien di lapangan, terutama pada era new normal ini, sehingga perawat dapat memahami cara perlindungan diri dan merawat pasien dengan Covid-19.

Stres kerja ialah stres yang dikaitkan dengan pekerjaan dan berkaitan dengan dampak buruk pada kondisi fisik serta kesejahteraan psikologis karyawan (Ekawarna, 2018). Berdasarkan hasil penelitian yang dilakukan terhadap 113 responden di Rumah Sakit Awal Bros A Yani didapatkan hasil perawat yang mengalami stres kerja tingkat ringan 30 orang $(26,5 \%)$, stres tingkat sedang 56 orang $(49,6 \%)$, stres tingkat berat 27 orang $(23,9 \%)$. Hasil penelitian ini senada dengan penelitian Afra \& Putra (2017) dengan karakteristik stres kerja mayoritas berada pada tingakatan sedang. Hal ini bisa saja disebabkan karena stresor organisasi, kelompok, maupun dari individu sendiri.(Afra \& Putra, 2017).

Penelitian ini menunjukkan bahwa terdapat $15,8 \%$ karyawan yang mengalami stres kerja tingkat berat. Hal ini tentu tidak dapat kita abaikan begitu saja. Stres dalam bekerja di era pandemi ini dapat disebabkan oleh kekhawatiran tentang tidak mampu memberikan perawatan yang kompeten, kekhawatiran tentang kesehatan diri, takut membawa infeksi ke anggota keluarga, stigmasisasi sosial bahkan beban kerja yang berlebih (El-Hage et al., 2020).Oleh karena itu, diperlukan konseling dan dukungan dari rekan sekitar terhadap tenaga kesehatan di era new normal ini.

\section{SIMPULAN}

Hasil penelitian menunjukkan karakteristik responden mayoritas berada pada tahap usia dewasa awal (26 tahun 35 tahun) dengan jumlah 56 responden, jenis kelamin perempuan sejumlah $71,7 \%$, status perkawinan belum menikah $65,5 \%$, tingkat pendidikan formal S1 Keperawatan + Ners 73,5 \%, memiliki masa kerja $>2$ tahun $38,6 \%$, pernah mengikuti pelatihan Covid-19 54.4\%, ruangan kerja responden mayoritas poliklinik 17,7 \%. Hasil penelitian untuk gambaran tingkat stres kerja perawat rumah sakit pada era new normal menunjukkan sebagian besar responden berada pada tingkatan stres sedang dengan 72 responden sebanyak $63,2 \%$.

Hasil penelitian gambaran tingkat stres kerja berdasarkan tingkatan usia mayoritas berada pada tingkatan stres sedang dengan hasil $63,7 \%$, berdasarkan jenis kelamin laki-laki berada pada tingkatan stres ringan dengan 40, 6\%, perempuan berada pada tingkatan stres sedang dengan $54,3 \%$, status perkawinan belum menikah berada pada tingkatan stres sedang dengan hasil $63,5 \%$, begitu pula dengan yang sudah menikah berada pada tingkatan stres sedang dengan hasil $54,1 \%$. Gambaran berdasarkan masa kerja responden berada pada tingkatan stres sedang $<1$ tahun (55.9\%), $1-2$ tahun $(74.3 \%),>2$ tahun $(61,4 \%)$, berdasarkan riwayat pernah mengikuti pelatihan Covid-19 berada pada tingkatan stres sedang dengan hasil 58,1 \%, tidak pernah mengikuti pelatihan Covid-19 berada pada tingkatan stres sedang dengan hasil 70,6 \%. Berdasarkan data ruangan responden sebagian besar berada pada tingkatan stres sedang kecuali ruangan UGD berada pada tingkatan stres ringan dengan persentase $50 \%$, ruangan ICU/ICCU/HCU berada pada tingkatan stres berat dengan persentase $46,7 \%$ serta endoskopi berada pada tingkatan stres 
berat dengan persentase $6,7 \%$.

Hasil penelitian ini diharapakan dapat menjadi bahan evaluasi bagi pihak rumah sakit untuk penanganan tingkatan stres kerja yang dihadapi perawat pada era new normal.

\section{DAFTAR PUSTAKA}

Afra, Z., \& Putra, A. (2017). Stres Kerja Perawat di Ruang Rawat Inap RSUD DR. Zainoel Abidin Banda Aceh. Skripsi. Fakultas Keperawatan Universitas Syiah Kauala Banda Aceh, 2(4). http://www.jim.unsyiah.ac.id/FKep/ar ticle/view/3864.

Dinkes Riau. (2020). Data Statistik Riau Tanggap Virus Corona. https://corona.riau.go.id/.

El-Hage, W., Hingray, C., Lemogne, C., Yrondi, A., Brunault, P., Bienvenu, T., Etain, B., Paquet, C., Gohier, B., Bennabi, D., Birmes, P., Sauvaget, A., Fakra, E., Prieto, N., Bulteau, S., Vidailhet, P., Camus, V., Leboyer, M., Krebs, M.-O., \& Aouizerate, B. (2020). Health professionals facing the coronavirus disease 2019 (COVID-19) pandemic: What are the mental health risks? National Library of Medicine. https://doi.org/10.1016/j.encep.2020. 04.008 .

Greenberg, J. (2013). Comprehensive Stres Management. In New York. McGrawHill Education.

Haryanti, Aini, F., \& Purwningsih, P. (2013). Hubungan Antara Beban Kerja dengan Stres Perawat di Instalasi Gawat Darurat RSUD Kabupaten Semarang. Jurnal Managemen Keperawatan, 1(1), 4856.

http://jurnal.unimus.ac.id/index.php/J MK/.article/view/949.

Jusnimar. (2012). Gambaran Tingkat Stres Kerja Perawat Intensive Care Unit (ICU) di Rumah Sakit Kanker Dharmais. Skripsi. Fakultas Ilmu
Keperawatan Universitas Indonesia. http://lib.ui.ac.id/file?file=digital/203 11866-S43387-Gambaran tingkat.pdf. Kang, L., Li, Y., Hu, S., Chen, M., Yang, C., Yang, B. X., Wang, Y., Hu, J., Lai, J., Ma, X., Chen, J., Guan, L., Wang, G., Ma, H., \& Liu, Z. (2020). The mental health of medical workers in Wuhan, China dealing with the 2019 novel coronavirus. The Lancet Psychiatry, 7(3), E14.

Kurniasih, Anggit, \& Widaryati. (2014). Gambaran Tingkat Stres Kerja Perawat di ICU RSUP DR. Sardjito. Yogyakarta: STIKES AISYIYAH Yogyakarta.

http:digilib.unisayogya.ac.id/id/eprint 1249 .

Marchelia, V. (2014). Stres Kerja Ditinjau dari Shift Kerja pada Karyawan. Jurnal Ilmiah Psikologi Terapan Universitas Muhammadiyah Malang, 2(1).

https://doi.org/https://doi.org/10.2221 9/jipt.v2i1.1775.

Muhyiddin, M. (2020). Covid-19, New Normal, dan Perencanaan Pembangunan di Indonesia. Jurnal Perencanaan Pembangunan: The Indonesian Journal of Development Planning, 4(2), 240-252. https://doi.org/10.36574/jpp.v4i2.118. Sujiato, M., Kandou, G. D., \& Tucunan, A. A. (2015). Hubungan Faktor Internal dan Eksternal dengan Tingkat Stres pada Mahasiswa Fakultas Kedokteran Universitas Sam Ratulangi Manado. JIKMU, 30-42.

Tayyib, N. A. G., \& Alsolami, F. J. (2020). Measuring the extent of stress and fear among Registered Nurses in KSA during the COVID-19 Outbreak. Journal of Taibah University Medical Sciences. Faculty of Nursing, Umm Al-Qura University, Makkah, KSA. https://doi.org/10.1016/j.jtumed.2020. 07.012.

Vahia, I. V, Blazer, D. G., Smith, G. S., Karp, J. F., Steffens, D. C., Forester, B. P., Tampi, R., Agronin, M., Jeste, 
D. V, \& Iii, C. F. R. (2020). COVID-19, Mental Health and Aging: A Need for New Knowledge to Bridge Science and Service. 7(July), 695-697. https://doi.org/10.1016/j.jagp.2020.03 .007 .

WHO. (2020). at the media briefing on 2019-nCov.

https://www.who.int/dg/speeches/ detail/who-director-generals.

Widiastuti, Y. (2018). Persepsi Beban Kerja dengan Tingkat Stres Perawat Ruang Operasi di RSUP Dr. Kariadi Semarang. Semarang: Universitas Muhamadiyah Semarang. http://repository.unimus.ac.id.

Widyasari, J. K. (2010). Hubungan antara kelelahan kerja dengan stres kerja pada perawat di rumah sakit islam yarsis surakarta. Surakarta: Jurusan Kesehatan Kerja Universitas Negeri Sebelas Maret. http://eprints.uns.ac.id/6316/1/159232 408201002181.pdf.

Worldmeters. (2020). Coronavirus update (live).

https://www.worldometers.info/coron avirus/. 